\title{
Re-Designing Higher Education Curriculum for Sustainable Development
}

\author{
Kipkoech Lydia Cheruto, Koross Rachel Chepchumba \\ University of Eldoret, Eldoret, Kenya \\ Rotumoi Joseph Tuitoek \\ University of Kabianga, Kericho, Kenya
}

\begin{abstract}
Kenyan higher education has grown tremendously in the recent years. Today, there is virtually a campus or an institution collaborating with a university in most urban centers. Following the promulgation of the new constitution in 2010 in Kenya, education is a basic human right. Consequently, it has continued to receive support from both the government and the private sector. Higher education has been commercialized as seen in the craze for establishment of some university campuses without sufficient learning and research facilities. What is more, individuals, parents, and benefactors are willing to go to all lengths to ensure that their children get degrees with the hope of uplifting their living standards. The Kenyan universities are graduating thousands of students each year to the job market, and hence, the huge numbers of graduates are unemployed. In the midst of all this, there is need for re-designing of the university curriculum to be more innovative and focus on meeting the government's development agenda as envisioned in Vision 2030 and a move towards achieving the millennium development goals (MDG) of poverty eradication. The future university ought to be on the forefront by providing sustainable solutions for the many challenges we faced. This paper discusses the various strategies that institutions of higher learning can adopt in a bid to be agents of sustainable development.
\end{abstract}

Keywords: curriculum, development, higher education, innovation, sustainability

\section{Introduction}

Education has played an important role in promoting sustainable development in Kenya and the world. The development of any nation is usually indicated by the degree and extent of the socio-cultural, socio-economic, and political improvement that are brought to bear through the enterprises of science, technology, and mathematics. According to Olorundare (2007), sustainable development led to fulfillment of societal ideals considered relevant to the needs and aspirations of the society.

Higher education is uniquely placed to play a leading role in the attainment of sustainable development in Africa, but this has not been the case in most universities. It is, therefore, not surprising to discover that universities and colleges that have committed to sustainability are struggling to meaningfully contribute to it (Lozano et al., 2010; Su \& Chang, 2010; Huisingh \& Mebratu, 2000). Glennerster, Kremer, Mbiti, and

Kipkoech Lydia Cheruto, Ph.D., lecturer, Department of Education Management, School of Education, University of Eldoret.

Koross Rachel Chepchumba, Ph.D., lecturer, Department of Education Management, School of Education, University of Eldoret.

Rotumoi Joseph Tuitoek, Ph.D., lecturer, Department of Education Management, School of Education, University of Kabianga. 
Takavarasha (2011) argued that education is widely seen as one of the most promising paths for individuals to realize better and more productive lives, and as one of the primary drivers of national economic development. The citizens and the government of Kenya have invested heavily in improving both the access and quality of education, in an effort to realize the promise of education as well as to achieve the education-related millennium development goals (MDGs) and Vision 2030. This calls for an urgent step in re-designing university curriculum so as to cope with the sustainable development goals (SDGs) having in mind that we are already in 2015.

The MDGs have been replaced by SDGs that explicitly link development to sustainability. Universities and colleges are facing this reality as they seek to meaningfully contribute to sustainability. Institutions of higher learning have also been faced with many challenges arising from increased student enrolment, liberalization of education system, and globalization of education in general. As a result of these pressures, universities have been challenged to maintain quality in curriculum development and delivery.

\section{Literature Review}

Currently, there is an upsurge of universities in most developing countries, and hence, too many graduates are in the saturated job market. Unlike the present, university graduates were most sought after in the past. According to Phillip (1997),

Schools are better than most critics, but the modern school system is less able to meet the demands of a contemporary society than were the schools in the past. The problem is that our society can no longer tolerate schools that produce so many students who meet the higher standards schools.

Higher educational institutions (HEIs) ought to participate in the development of their countries through training, supporting, and promoting innovations that will provide solutions to the challenges faced. United Nations Educational, Scientific, and Cultural Organization (UNESCO, 2014) identified two unique opportunities for HEIs to engage in sustainable development. Universities form a link between knowledge generation and transfer of knowledge to society for their entry into the labour market. Such preparation includes education of teachers, who play the most important role in providing education at the formal and informal setup. Universities also actively contribute to the societal development through collaboration, outreach, identifying, nurturing talents, and social corporate responsibilities. Cortese (2003) supported this assertion by stating that,

Higher education institutions bear a profound and moral responsibility to increase the awareness, knowledge, skills, and values needed to create a just and sustainable future. Higher education often plays a critical, but often overlooked role in making this vision a reality. It prepares most of the professionals who develop, lead, manage, teach, work in, and influence society's institutions.

Currently in Africa, citizens are demanding for quality and affordable education. Education and health issues have become political campaign tools that have been used in all elections since independence. This indicates the important role of education plays in the development of a nation. The citizenry goes to every length to secure higher education for their children, and hence, the infiltration of many unregulated institutions taking advantage of this scenario. Moreover, the Kenyan government's expansion of university education has given universities and colleges a leeway to operate freely in order to meet the high demand for university education.

Consequently, the universities move to start constituent colleges and campuses appear to be regional and politically driven attests to the government's commitment to meet the demand for higher education. As the 
effects of the increase in student numbers have become more apparent in student achievement and retention, the call for ever more demanding and intrusive processes of quality assurance has become stronger. Such processes are designed to reassure both politicians and students that their public and private investment in higher education is giving them value for money (Harvey, Locke, \& Morey, 2002).

The developed countries have taken advantage of this appetite for higher education. Several agencies working for foreign institutions that are not recognized have established bases in Africa's major cities to recruit susceptible students to their institutions. Consequently, there is also proliferation of university campuses in every town, some of which have no resources while others are in deplorable learning environment. The particular concern is that the staffing levels in these campuses inhibit innovation. This is due to the fact that university research output is limited by the low percentage of academic staff with Ph.D. training and qualifications. Altbach (2002) commented that,

Academic staffs in African universities have very limited resources, leading to lower motivation. They do not have the necessary resources to play the role of mentors, training graduate students, and to contribute to knowledge production and dissemination. They are faced with low remuneration and overcrowded institutions. Moreover, the position of African academics at the "periphery" of knowledge production makes it difficult for them to substantially contribute to innovation, because they are reliant on academic research performed in developed countries.

Furthermore, individual academics in Africa appear to have been particularly hard-hit, even by constraining working conditions, although these challenges are not unique to Africa (Enders \& Teichler, 1997). Higher education for sustainability must address challenges affecting humanity, such as human rights abuse, poverty reduction, conflict, environmental degradation, bad governance, wastage, corruption, climate change, gender inequality, and marginalization of indigenous cultures.

However, in the recent past, public concern about the quality of education is at an all-time high and public confidence in the ability of educators to address these concerns is at an all-time low. Especially with the conviction from teachers asserting that given societal pressures and a lack of parental involvement, the schools are doing as well as possible (Frakas \& Johnson, 1996). Therefore, institutions of higher learning have the responsibility, more than ever before, to integrate sustainable development into all their teaching, research, innovation, community engagement and campus management. They also should engage people in creating and contributing meaningfully towards a sustainable future.

In addition to other recent declarations, like the Nagoya Declaration on Higher Education for Sustainable Development in November, 2014, call for a transformation of higher education in order to better foster sustainable development through an institutionwide approach that reflects all of the different roles and dimensions of HEIs (Lozano et al., 2010).

The year 2015 is particularly important for international development, because it ushers in the United Nations' (UN's) new SDGs (2016-2030) as the MDGs (2000-2015) come to an end. Consequently, the success of its implementation will require substantial inputs from HEIs and support from all stake-holders.

The role of education for sustainable development is to help people develop attitudes, skills, and knowledge to make informed decisions for the benefit of themselves and others, now and for the future, and to act upon those critical decisions. Consequently, universities require fundamental re-examination of the assumptions upon, which the system of education is based and a willingness to modify those assumptions in ways that take into account the emerging realities of the 21st century. This paper argues that this requires going beyond the integration of key ideas in existing curriculum and supporting the sustainability action projects. 
Instead, the sustainability journey should engage universities and colleges in a quest for inter-disciplinary, participatory pedagogies, research, and the opening of institutional boundaries, so that the notion of sustainable communities is extended beyond university and college walls. This paper further suggests strategies that need to be adapted to sustainable development.

\section{The Need for Curriculum Re-Design in Universities}

Curriculum refers to all the student activities (academic and non-academic) for which an institution takes responsibility. These activities, particularly the learning programmes, have an impact on student's learning, goals, and outcomes. HEIs must continually review their curriculum as a response to the changes and challenges in the world, such as terrorism, climate change, unemployment, and poverty among others. The world has also become a global village, and hence, institutions must adjust in order for them to remain competitive and relevant.

However, curriculum review should be done to enable institutions of learning to contribute to sustainable development. According to the Organization for Economic Co-operation and Development (OECD) report (2007), it seemed that a global consensus has emerged, where teaching should be transformative in nature, suggesting the explicit consideration of ethics, values, and spirituality, experiential learning, and well-developed reflective skills in students. There was an acknowledgement that stand-alone sustainability courses were useful, but they were always seen as a stepping-stone to the real goal of integration into the core curriculum.

Teaching by nature is about changing student's ideas and influencing behaviour, so it is anticipated that teaching for sustainable development would accord with this notion. The 2010 constitution declared education as a basic right of every child as a step towards sustainable development. This view is supported by Dr. Jim Yong Kim (2013), president of the World Bank Group, when he asserted that,

Every child should have the opportunity not only to go to school, but also to acquire the knowledge and skills. He/she needs to lead a healthy and productive life, care for herself and her family, and become an empowered citizen. At the national level, countries need workforces with the skills and competencies required to keep farms and factories producing, create jobs, fuel innovation and competitiveness, and drive economic growth that benefits everyone.

Universities in Africa must endeavor to compete with their counterparts in the west who have particularly benefitted from brain drain. The performance of universities in Africa in the global ranking has been used as a justification for the top students to move abroad in search of quality education. Further, the curriculum in most of the African institutions is theoretical and not transformative. According to World Bank (2013), only five African countries registered more than 100 patents, while most of the remaining African countries did not register any. This lack of innovation impedes development and African economies from successfully pursuing and accelerating structural transformation. There is need for curriculum re-design to incorporate emphasis on innovation that will not only benefit the individuals and institutions, but the economic transformation.

The recognition of the government's role both in central and county level in achievement of sustainable development is crucial and should be acknowledged at all educational levels. The private sector and communities should support the government in financing and influence policy that will promote sustainability, so that education can be used to address poverty and illiteracy. The education institutions should utilize information communication technology (ICT) to enhance development. This is through the establishment of hubs and incubation centres that nurture innovators. According to UN Development Program (UNDP, 2001) report, among African countries, only Algeria, Egypt, Tunisia, South Africa, and Zimbabwe were ranked in the 
group of dynamic adopters, which were characterized by a vibrant use of new technology as well as development of high-technology industries and technologies hubs.

Furthermore, university-industry collaboration can also expand the relevance of research carried out in public institutions, foster the commercialization of public research and development outcomes, and increase the mobility of labor between public and private sectors. The benefits of university-industry collaboration are also evident in developing countries. For example, a study in 2007 showed that collaboration with universities substantially increased the propensity of firms to introduce new products and to patent (Marotta, Mark, Blom, \& Thorn, 2007).

Education should enhance peace and solve conflicts. Education strengthens inclusive, participatory and representative decision-making promote human rightsand rule of law. UNESCO (2014) report added, "Every individual and every organ of society ... Shall strive by teaching and education to promote respect for these rights and freedoms.” Therefore, good quality education enables people to make informed judgements about issues that concern them and engage more actively and constructively in national and local political debates.

In many parts of the world, however, unfair elections, corrupt officials, and weak justice systems jeopardize human rights and citizens' confidence in government. When disenfranchised groups feel they have no means to voice their concerns, such failures can lead to conflict. Peace and security is the most important public good and it is widely accepted that development cannot occur without peace. Freedom from conflict and violence is an important development outcome, but peace also underpins the achievement of other global development goals, such as poverty eradication, socio-economic development, and gender equality (MDG Report, 2014). Education is a key mechanism promoting tolerance to diversity. This can be done through re-designing the curriculum that promotes diversity and good governance. It is important to recognize the crucial role education plays in contributing to peace building and a culture of peace. Education for peace implies an active concept of peace through values, life skills, and knowledge in a spirit of equality, respect, empathy, understanding, and mutual appreciation among individuals, groups, and nations.

\section{Strategies That Should be Adopted by Universities for Sustainable Development}

\section{Integration of Key Issues in the Existing Curriculum}

Many countries have been integrating the MDGs into national development framework and strategies, and using them to help monitor progress. This has been done in most Kenyan universities whereby the key issues in the MDGs have been integrated into the curriculum, but there are still challenges in achieving the desired MDGs. Universities should use the existing resources and capabilities to orientate their activities more directly towards supporting MDGs. Universities have programs on human immunodeficiency virus (HIV), acquired immune deficiency syndrome (AIDS), safety measures, human rights, and terrorism among other emerging issues with university staff, students, communities, and other stake-holders, but this has not been effectively done for sustainable development. Therefore, universities should promote inculcation and transition of MDGs into every facet of institutional operations (MacGregor, 2010). Universities can also integrate the SDGs in the curriculum by offering compulsory courses that address the SDGs or providing a compulsory module for all students infusing values and focuses on the SDGs.

In addition, universities should teach sustainable development concepts, ensuring that they form a part of the core curriculum across all disciplines, so that future higher education graduates develop skills necessary to enter sustainable development workforces. Also, they have an explicit understanding of how to achieve a 
society that values people, the planet, and profits in a manner that respects the finite resource boundaries of the earth. Universities are also encouraged to provide sustainability training to professionals and practitioners. Therefore, the university curriculum should address changing needs and equip students with skills that enhance self-reliance and entrepreneurial skills.

\section{Initiating Projects Which Address Key Sustainability Issues}

University management boards together with the national government and the county governments should ensure that they support projects that promote sustainability. Key projects, such as community projects that elevate poverty, those that can support agriculture and ensure food sustainability, other projects, like environmental conservation, educating the public on prevention of diseases, such as malaria, cholera, HIV, AIDS, and other threatening diseases that can be controlled or eradicated in the society and gender issues such as female genital mutilation (FGM).

Universities are known to have led to social change through scientific breakthroughs but also through the education of intellectuals, leaders, and future-makers (Lozano, 2006; Tilbury, Coleman, \& Garlick, 2005). Stern (2010) asserted that higher education can change the world through the following ways:

1. Training and expanding young minds;

2. Researching answers to challenges and informing public policy;

3. Showing its own understanding and commitment through careful campus management;

4. Being a responsible employer and active member of the business and local communities.

In an era of globalization, universities and colleges also have an impact through their global procurement, offshore partnerships as well as through the education of national and international students. For example, in Senegal, where the Annual Civic Camps are organized by the universities have become a success. Their potential influence on economic development, poverty alleviation, and health and community building should not be overlooked (Boks \& Diehl, 2006; Galang, 2010; Lotz-Sisikta, 2011).

\section{Initiating Courses at University Level That Address the Key MDGs Directly}

The development of specialist course in the specific areas can provide an opportunity to shape minds and practices and also attempt to mainstream this agenda across higher education in Africa. Universities can re-design the curriculum in such a way that they offer courses that directly address the SDGs. Such courses may result in degrees or diploma certificates in various areas, such as disaster management, climatic change, agriculture and food insecurity, nutrition, energy, environmental education, business management, public health with a keen eye in emerging diseases, gender issues, and human rights.

Moreover, the use of the existing courses in the curriculum across various disciplines to give effect to individual goals, such as agricultural sciences, engineering, rural development, education, medicine, social work, etc.. Using open and distance learning programs, teacher training, gender policy and mainstreaming and using faculties, such as social work, education, and medicine to train communities on the various issues are also the existing courses in the curriculum.

\section{Universities and Colleges Inter-Disciplinary Relations}

Universities and colleges should engage in an inter-disciplinary approach, participatory pedagogies, real research, and the opening of institutional boundaries, so that the notion of sustainable communities is extended beyond university and college walls. Universities should enhance internal and external collaboration and networking between universities and faculties/schools. These collaborations should maximize the efficiency of 
existing partnerships, eliminate duplication, and identify possible areas for introduction of additional partners.

Additionally, a social movement is occurring at universities worldwide to promote strategies and processes for creating more sustainable campuses. This movement began with a number of international declarations and commitments made by universities around the globe (Wright, 2002). For example, the Thessaloniki Declaration (1997) affirmed that all subject disciplines must address issues related to the environment and sustainable development and that university curriculum must be reoriented towards a holistic approach to education (Wright, 2002, p. 111).

\section{Training and Research}

Universities should encourage research on sustainable development issues, to improve scientific understanding through exchanges of scientific and technological knowledge, enhancing the development, adaptation, diffusion, and transfer of knowledge, including new and innovative technologies. Furthermore, universities should promote intellectual engagement on the MDGs by holding discussions among students and staff. This will enhance the passing of knowledge and raising awareness of issues on sustainable development. Inter-university teaching and research between the north and the south should be encouraged

\section{Recommendations}

There are some recommendations as the following:

1. Institutions of higher learning in Kenya could adopt some of the models that have been successfully implemented in some institutions. For example, corporate graduate link (CoGL) among the University of Zambia, chamber of commerce, and some development partners, like Germany. This linkage aims at designing a curriculum in the universities that addresses the needs of the employment market and the vision of the country;

2. The curriculum to be re-designed to enhance sustainability by encouraging innovation, new ideas, and change that will bring about new ways of doing things in organizations, such as higher learning institutions;

3. Universities ought to building corporate image and establish a curriculum that addresses government's development policies and strategies;

4. Higher education should give new meaning to the old adage that students learn, by doing so, the curriculum developed ought to encourage the learners to produce knowledge, think reason, and use their minds well;

5. The industries could support research projects post-graduates in order to influence the curriculum design to be responsive to private sector demands and job market;

6. Inter-university collaborations ought to be encouraged and emphasized. These collaborations should maximize the efficiency of existing partnerships, eliminate duplication, and identify possible areas for introduction of additional partners;

7. Harmonization of curriculum of HEIs and emphasis on quality could be the focus of the various commissions of higher education in Africa.

\section{Conclusion}

For a country to be internally competitive and economically viable, it requires an education system that will produce citizens who are able to engage in lifelong learning, learn new skills quickly, perform more routine tasks, capable of more complex problem solving make more decisions, understand more about what they are working on, require less supervision, assume more responsibility, and have more vital tools, have 
better reading culture, quantitative analysis, and reasoning and expository skills. Therefore, education is an essential driver of sustainable development and transformation of society.

\section{References}

Altbach, P. G. (2002). Knowledge and education as international commodities. International Higher Education, 28, 2-5.

Boks, C., \& Diehl, J. C. (2006). Integration of sustainability in regular courses: Experiences in industrial design engineering. Journal of Cleaner Production, 14(9-11), 932-939.

Cortese, A. D. (2003). The critical role of higher education on creating a sustainable future. Planning for Higher Education, 31(3), $15-22$.

Enders, J., \& Teichler, U. (1997). A victim of their own success? Employment and working conditions of academic staff in comparative perspective. Higher Education, 34, 347-372.

Farkas, S., \& Johnson, J. (1996). Given the circumstances: Teachers talk about public education today. New York, N.Y.: Public Agenda.

Galang, A. P. (2010). Environmental education for sustainability in higher education institutions in the Philippines. International Journal of Sustainability in Higher Education, 2(4), 138-150.

Glennerster, R., Kremer, M., Mbiti, I., \& Takavarasha, K. (2011). Access and quality in the Kenya education system: A review of the progress, challenges, and potential solutions. In A report prepared for the office of the Prime Minister. Nairobi, Kenya.

Harvey, L., Locke, W., \& Morey, A., (2002). Enhancing employability, recognising diversity. London, Universities UK.

Huisingh, G., \& Mebratu, D. (2000). Educating the educators as a strategy for enhancing education on cleaner production. Journal of Cleaner Production, 8, 439-442.

John, A. (2007). Leadership for Innovation: How to organize team creativity and harvest ideas. London: Kogan Page.

Jim, Y. K. (2013). Poverty, health and the human future. Geneva, Switzerland: World Health Assembly.

Lozano, R. (2006). Incorporation and institutionalization of SD into universities: Breaking though barriers to change. Journal of Cleaner Production, 14(9-11), 787-796.

Lozano, R., Lukman, R., Lozano, F. J., Huisingh, D., \& Zilahy, G. (2010). Jumping sustainability meme: SD transfer from society to universities. In The environmental management for sustainable universities. Delf, Netherlands.

Lotz-Sisitka, H. (2011). The event of modern sustainable development and universities in Africa. In Higher education in the World 4-Higher education's commitment to sustainability: From understanding to action. GUNI: Barcelona.

MacGregor, K. (2010). Global: Higher education a driver of MDGs. University World News, 122.

Mader, C., Scott, G., \& Razak, D. (2013). Effective change management, governance, and policy for sustainability transformation in higher education. Sustainability Accounting Management and Policy Journal, 4(3), 264-284.

Marotta, D., Mark, M., Blom, A., \& Thorn, K. (2007). Human capital and university-industry linkages’ role in fostering firm innovation: An empirical study of Chile and Colombia (English). In Policy Research Working Paper (WPS 4443). Washington, D.C.: World Bank.

Millennium Development Goals (MDG) Report. (2014). Assessing progress in Africa toward the MDGs. Addis Ababa, Ethiopia: Economic Commission for Africa.

Organisation for Economic Co-operation and Development (OECD). (2007). Higher education and regions: Globally competitive, locally engaged. Paris: Author.

Olorundare, S. (2007). Utilization of information and communication technology (ICT). In D. N. Ezeh \& N. Onyegegbu (Eds.), Curriculum development implementation technology in the service of education (pp. 57-66). Enugu: Timex.

Phillip, C. S. (1997). Inventing better schools: An action plan for educational reform. San Fransisco: Jossey-Bass Inc..

Stern, N. (2010). Indide government interactive forms and conference. Retrieved June 1, 2011 from http://www.insidegovernment. co.uk/environment/higher-education-sustainability/

Su, H. J., \& Chang, T. C. (2010). Sustainability of higher education institutions in Taiwan. International Journal of Sustainability in Higher Education, 11(2), 163-172.

Tilbury, D., Coleman, V., \& Garlick, D. (2005). Education about and for sustainability in Australia Bussiness School. In A report prepared by ARIES and Arup austainability for the DEH. Canberra.

United Nations Educational, Scientific, and Cultural Organization (UNESCO). (2004). Education for sustainable development. Paris: Author.

UNESCO. (2014). Sustainable development begins with education. Paris: Author. 
United Nations Development Program (UNDP). (2001). Human Development Report 2001. Retrieved from http://hdr.undp.org/en/ content/human-development-report-2001

Wiek A., Withycombe L., \& Redman C. L. (2011). Key competencies in sustainability: A reference framework for academic programme development. Sustainability Science, 6(2), 203-208.

Wright, T. S. A. (2002). The effect of the Halifax declaration on Canadian signatory universities: A tenth year anniversary retrospect-Policy, change and environmental sustainability in the university (Unpublished Ph.D. dissertation, University of Alberta, Canada).

World Bank. (2013). The World Bank Annual Report 2013. Washington, D.C.: Author. Retrieved from https://openknowledge. worldbank.org/handle/10986/16091 